\title{
Magnetostratigraphy and rock magnetism of the Boom Clay (Rupelian stratotype) in Belgium
}

\author{
D. Lagrou ${ }^{\star}$, N. Vandenberghe ${ }^{1}$, S. Van Simaeys ${ }^{1} \&$ J. Hus ${ }^{2}$ \\ 1 Historische Geologie, KU Leuven, Redingenstraat 16, 3000 Leuven, Belgium \\ 2 Centre de Physique du Globe de l'IRM, 5670 Dourbes, Belgium \\ * Corresponding author: D. Lagrou, presently at the Flemish Institute for Technological \\ Research (Vito), Boeretang 200, B-2400 Mol, Belgium. E-mail: david.lagrou@vito.be
}

Manuscript received: February 2004; accepted: August 2004

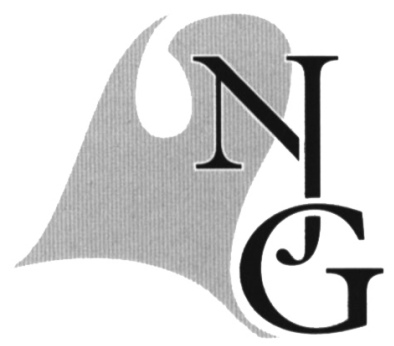

\begin{abstract}
This paper presents the results of a detailed rock magnetic and magnetostratigraphic study of the Lower Oligocene Rupelian unit-stratotype. Notwithstanding the relatively low intensity of the natural remanent magnetisation and the diverse and often unstable behaviour during demagnetisation, close-spaced sampling and accurate polarity determinations allowed us to determine the magnetic polarity zonation. The recognition of the characteristic magnetic polarity and the correlation with the standard magnetobiochronologic time scale yields an accurate chronostratigraphic dating of the Boom Clay Formation. The boundary between the geomagnetic chrons $\mathrm{C} 12 \mathrm{n}$ and $\mathrm{C} 12 \mathrm{r}$ nearly coincides with the lithostratigraphic boundary between the Terhagen and Putte Members. Rock magnetic techniques point to magnetite and probably also iron sulphides as the main magnetic remanence carriers. These magnetic minerals could, however, not be identified with classical mineralogical techniques performed on magnetic extractions. The failure to detect them may be due to the low concentration of these minerals, the small grain size, and the close physical relation with pyrite.
\end{abstract}

Keywords: Boom Clay Formation, iron sulphides, magnetostratigraphy, rock magnetism, Rupelian

\section{Introduction}

This paper describes the rock magnetic characteristics and magnetostratigraphy of the Lower Oligocene Boom Clay Formation in the Rupelian stratotype (Belgium). This shallow marine unit is well exposed in outcrops along the Rupel river in northwest Belgium (Fig. 1) and consists of alternating stiff clays and clayey silts with a quasi-periodicity of approximately $0.5 \mathrm{~m}$ (Vandenberghe, 1978). At certain levels carbonate-rich horizons occur and often contain large concretions, known as septaria (Vandenberghe \& Laga, 1986; the S-layers in Fig. 2). Correlation between the different outcrop sections led to the observation that all the individual layers extend along the strike over an exposure area of more than $50 \mathrm{~km}$. Therefore, a composite stratigraphic column can be used for further discussion (Vandenberghe et al., 1997). The formation in the outcrop area is subdivided in three lithostratigraphic members: a lower 9 meter $(\mathrm{m})$ thick sandy Belsele-Waas Member, a middle, $12 \mathrm{~m}$ thick, greycoloured Terhagen Member and an upper darkcoloured Putte Member (about $20 \mathrm{~m}$ thick in the outcrop area), containing many black horizons rich in organic material (Vandenberghe \& Van Echelpoel, 1987). Two major cycles have been recognised on the basis of grain size analysis (Vandenberghe et al., 1997). They represent the two third-order depositional sequences of Haq et al. (1987) (Fig. 2). However, the correlation of the two third-order eustatic sequences with the three sequences figured on the global relative sea-level chart for the Rupelian (Hardenbol et al., 1998) is not well understood. This is mainly due to poor biostratigraphic dating although many macro- and 


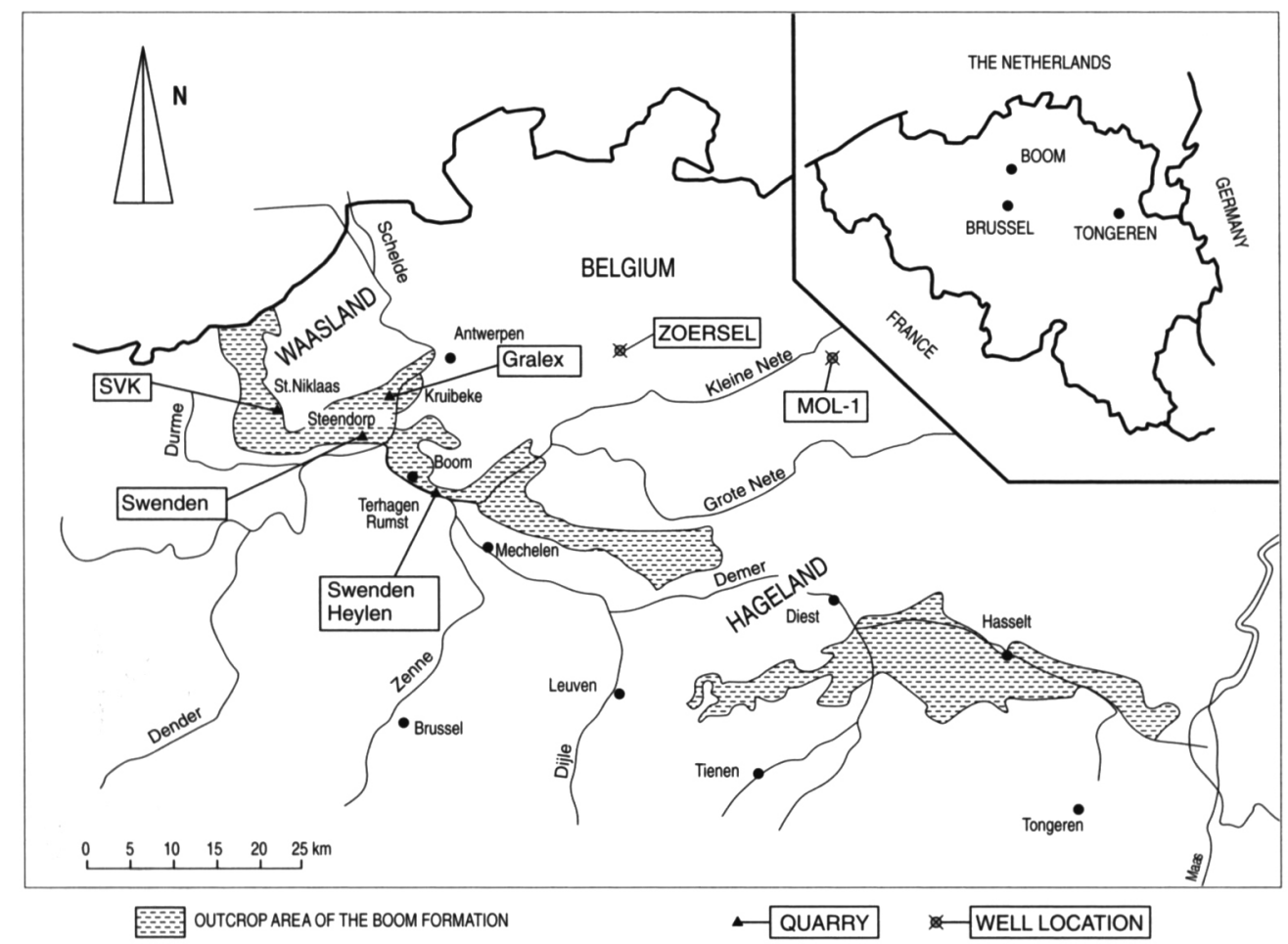

Fig. 1. Outcrop area of the Boom Clay Formation in Belgium (afterVandenberghe et al., 1997), the sampled outcrops pits and boreholes are indicated. micropaleontologic investigations were carried out on the outcrop sections. Hooyberghs $(1983,1992)$ attributes the Boom Clay Formation to Blow's (1979) planktonic foraminiferal zones P18-P21, while nannoplankton investigations (Steurbaut, 1986, 1992) revealed that the outcrop section relates to Martini's (1971) nannoplankton zone NP23. It is in this context that the magnetostratigraphy becomes a very important stratigraphical tool. The recognition of the characteristic magnetic polarity and a subsequent correlation with the standard chronostratigraphic chart of Berggren et al. (1995) may provide an additional key in the age determination.

Preliminary magnetostratigraphic investigations of the Boom Clay Formation (Hailwood \& Ting, 1990; Lagrou, 1992) showed a very weak magnetic signal and an unstable behaviour during demagnetisation. These unfavourable magnetic properties hamper the clear (unambiguous) identification of magnetozones and interpretation of the polarity data. Therefore, an additional and extensive rock magnetic study was carried out in order to understand the magnetic properties and magnetic mineral content.

\section{Sampling and Methods}

The Boom Clay in the outcrop area was sampled in five overlapping sections (Fig. 2): the lower part in the in St-Niklaas (SVK clay pit), the middle parts in Rumst, Steendorp (clay pit Swenden), and Terhagen (clay pit Heylen), and finally the upper part in Kruibeke
(Gralex clay pit). Because all sampled clay pits are still in production, the surface weathering of the clay is reduced to a minimum. The outcrop was first excavated $20 \mathrm{~cm}$ to remove possible mechanical disturbances induced during exploitation. Centimetre to decimetre sized, oriented hand samples were cut from the centre of each layer as well as about $0.3 \mathrm{~m}$ above and below it. Before retrieving them they were oriented by making a horizontal surface on which an orientation line of known magnetic azimuth was marked. In the laboratory at least two standard cubes $(2.4 \mathrm{~cm})$ per hand sample were carefully cut by knife, again to minimise mechanical disturbances. The samples were wrapped in a plastic film and kept at $4^{\circ} \mathrm{C}$ to prevent drying out during subsequent laboratory analysis.

Because the sampling technique (hereafter called the cube sampling technique) was very time consuming, a second, more rapid sampling technique was tested. It consisted of taking cylindrical samples by gently hammering approximately $15 \mathrm{~cm}$ long, thin-walled split halve stainless-steel corers $(2.54 \mathrm{~cm}$ inner diameter) perpendicularly into the cleaned wall of the pit with the aid of a piston, guided by a hollow aluminium cylinder mounted on a plate (Fig. 3). The samples were oriented with an orientation device similar to the one currently used to orient drilled cores. As shown in Fig. 3, the corer can easily be opened to extract the sample. In the laboratory, the cores were sliced into $2.5 \mathrm{~cm}$ long cylinders.

The cube sampling technique in sediments, especially in clayey horizons, was preferred over the 


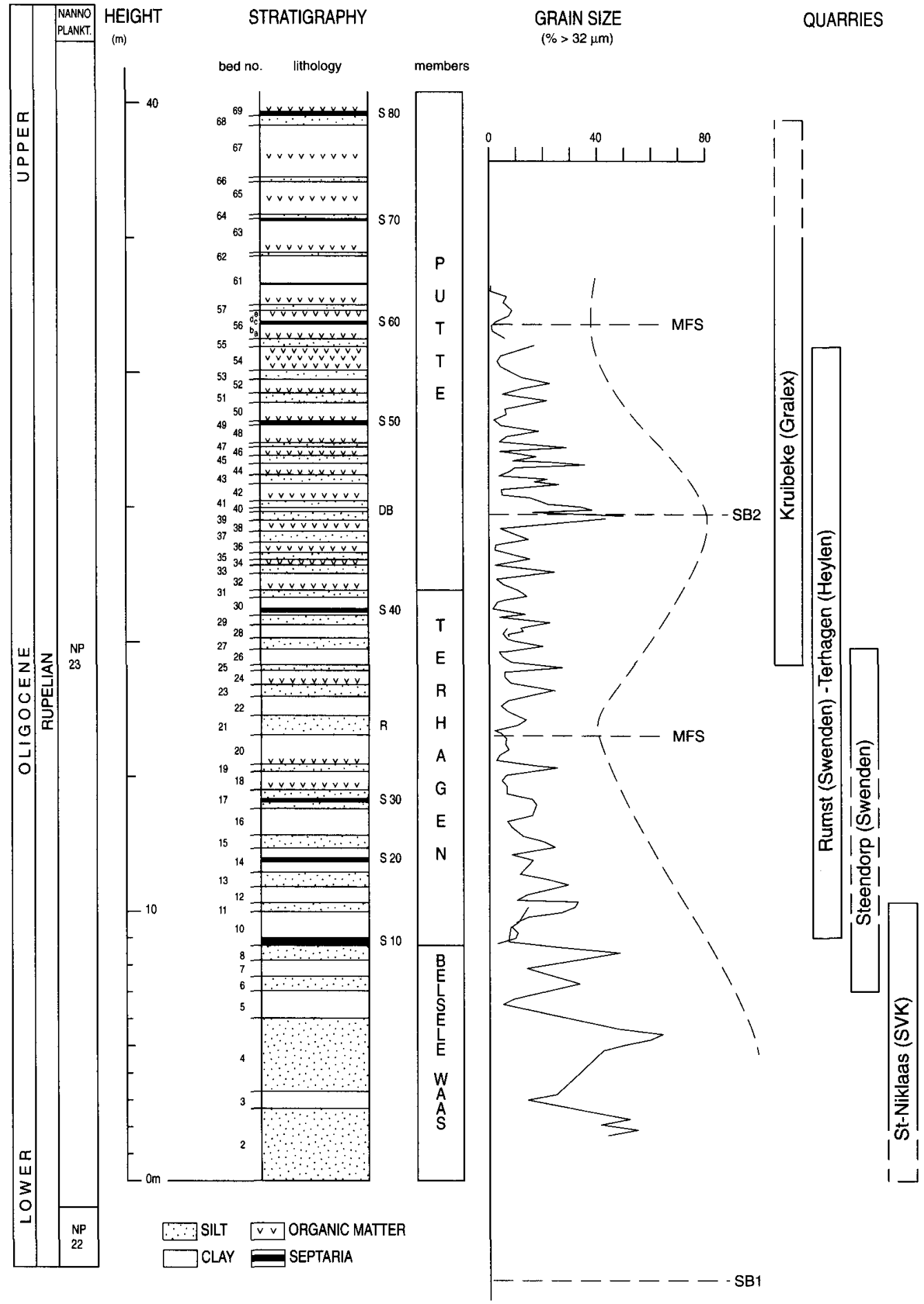

Fig. 2. The composite stratigraphical section of the Boom Clay in the outcrop area with lithostratigraphic subdivisions, lithologic variables and paleontological data. The sampled intervals in the different quarries are shown at the right hand side of the figure. The dotted line shows the grain size trend enveloping the high frequency grain size variations.

cylindrical technique as it induced fewer disturbances. However, it is very time consuming in the field and in the laboratory. Unfortunately it could not be implemented in silty horizons, because of their crumbly behaviour.

Although the cylindrical technique is very efficient (the field samples already have the required diameter; hence, sample preparation in the laboratory is reduced to a minimum), mechanical disturbances cannot be completely avoided, and hammering of the split halve corer results in compaction and shearing of the sediment, causing larger disturbances in silt layers than in clay layers.

The natural remanent magnetisation (NRM) of the samples was measured in a three-axis, $2 \mathrm{G}$ cryogenic model 760 magnetometer. Room temperature bulk magnetic susceptibility $(\chi)$ was measured in a kappabridge KLY-1. Stepwise, alternating field (a.f.) demagnetisation was performed in a demagnetisation unit linked to the $2 \mathrm{G}$ cryogenic rock magnetometer. The samples were incrementally demagnetised by the a.f. method, usually at steps of 5 milli Tesla (mT), up to 


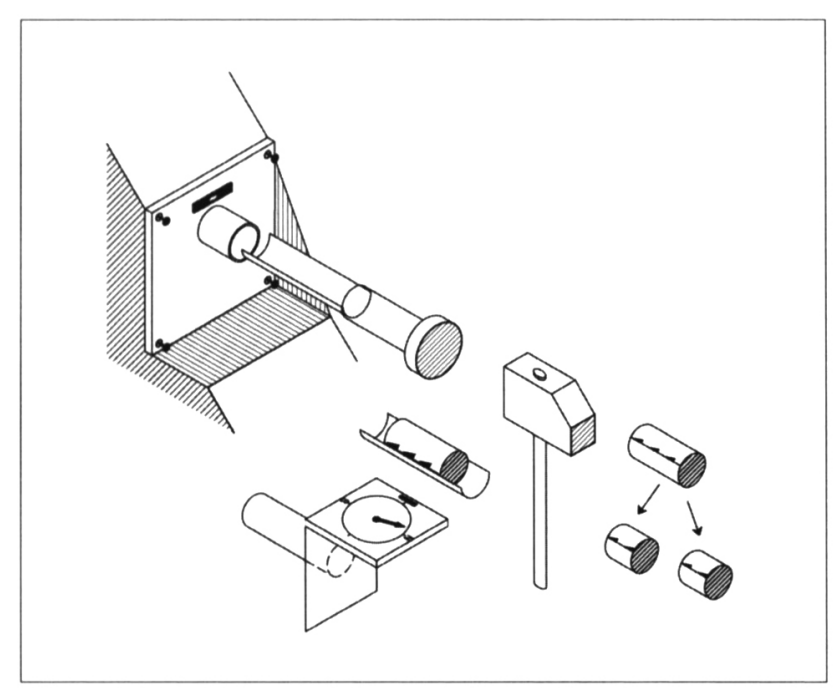

Fig. 3. Schematic presentation of the cylindrical sampling technique.

30-40 mT. Stepwise thermal demagnetisation was done in a non-magnetic Schonstedt TSD oven. Samples were heated and cooled in a zero magnetic field in air. The samples were initially measured at room temperature, and subsequently after heating at $70^{\circ} \mathrm{C}, 170^{\circ} \mathrm{C}$ up to $220^{\circ} \mathrm{C}$. From that temperature on, measurements were taken at $25^{\circ} \mathrm{C}$ increments, up to $370^{\circ} \mathrm{C}$. The magnitude of the temperature steps was defined by the following: (1) It is expected that the viscous remanent magnetisation (VRM) is removed after heating at 150 to $200^{\circ} \mathrm{C}$. Up to $220^{\circ} \mathrm{C}$ relatively large temperature steps were taken to minimise the number of heating-cooling cycles, as mineralogical transformations (especially pyrite oxidation) are known to occur at relatively low temperatures. From $220^{\circ} \mathrm{C}$, the temperature steps were decreased to increments of $25^{\circ} \mathrm{C}$ to better monitor the unblocking temperature spectra or thermal transformation of remanence carriers.

Isothermal remanent magnetisations (IRM) were given to the samples in a field-controlled Varian 6-inch electromagnet (max. field 1 tesla $(T)$ ). Thermomagnetic curves were measured in air using the technique of Mullender et al. (1993), on two bulk samples at the paleomagnetic laboratory at the University of Utrecht.
Magnetic extraction on some samples was performed with a Franz isodynamic magnetic separator. These extractions were studied with Scanning Electron Microscopy (SEM), X-ray Diffraction (XRD), optical reflected light microscopy, and microprobe analysis. Before extraction, the sediment was split into three grain size fractions by wet sieving: a fraction of grains $>500 \mu \mathrm{m}$, a fraction between 500 and $90 \mu \mathrm{m}$, and a fraction $<90 \mu \mathrm{m}$. The first separation was tried using a small magnet in a sealed bag into the agitated suspension of the different fractions. No magnetic grain could be collected with this technique. In a second trial, taken from the two other grain size fractions, suspensions were made from 30 grams $(\mathrm{g})$ of sediment in 4 litres of demineralised water. In total, 300 $\mathrm{g}$ sediment of each grain size fraction were prepared. The suspensions were passed through a glass tube between the poles of the magnetic separator operating at a high current ( 1.5 ampère (A)). After each passage, the mineral grains attracted by the magnet were washed from the tube. The first magnetic concentrates consisted mainly of clay minerals and were subjected to a second concentration step to separate the strongly magnetic fraction. The suspension was again passed between the poles of the magnetic separator at a low current $(0.5 \mathrm{~A})$. The two resulting concentrated fractions still contained considerable amounts of clay minerals.

\section{Rock Magnetism}

\section{NRM and magnetic susceptibility}

The NRM intensity of the Boom Clay varies between 0.06 and 3.21 milli Ampère per meter $(\mathrm{mA} / \mathrm{m})$ with an average of $0.40 \mathrm{~mA} / \mathrm{m}$ (Fig. 4 and Table 1). The majority of the intensities are between 0.10 and 1.00 $\mathrm{mA} / \mathrm{m}$. Evaluated separately, the average values for the silt layers, clay layers, and distinguished stratigraphic members are comparable. This is an indication that the amount of magnetic remanence carriers in the formation does not vary significantly.

Table 1. NRM and $\chi$ intensities subdivided to lithology and lithostratigraphic members.

\begin{tabular}{lccc|ccc}
\hline & $\begin{array}{l}\text { Number } \\
\text { of samples }\end{array}$ & $\begin{array}{l}\text { NRM } \\
\text { (in mA/m) }\end{array}$ & $\begin{array}{l}\text { Standard } \\
\text { deviation }\end{array}$ & $\begin{array}{l}\text { Number } \\
\text { of samples }\end{array}$ & $\begin{array}{l}\chi \\
\text { (in 10-9 } \mathbf{m}^{3} / \mathbf{k g} \text { ) }\end{array}$ & $\begin{array}{l}\text { Standard } \\
\text { deviation }\end{array}$ \\
\hline $\begin{array}{l}\text { Lithology } \\
\text { Clay layers }\end{array}$ & 192 & 0.40 & 0.36 & 148 & 79.36 & 13.86 \\
$\begin{array}{l}\text { Silt layers } \\
\text { Members: }\end{array}$ & 112 & 0.37 & 0.31 & 92 & 86.62 & 11.11 \\
Putte & 80 & 0.44 & 0.41 & 56 & 67.64 & 9.01 \\
Terhagen & 72 & 0.40 & 0.19 & 58 & 80.81 & 15.41 \\
Belsele-Waas & 108 & 0.40 & 0.45 & 72 & 81.61 & 10.74 \\
\hline
\end{tabular}




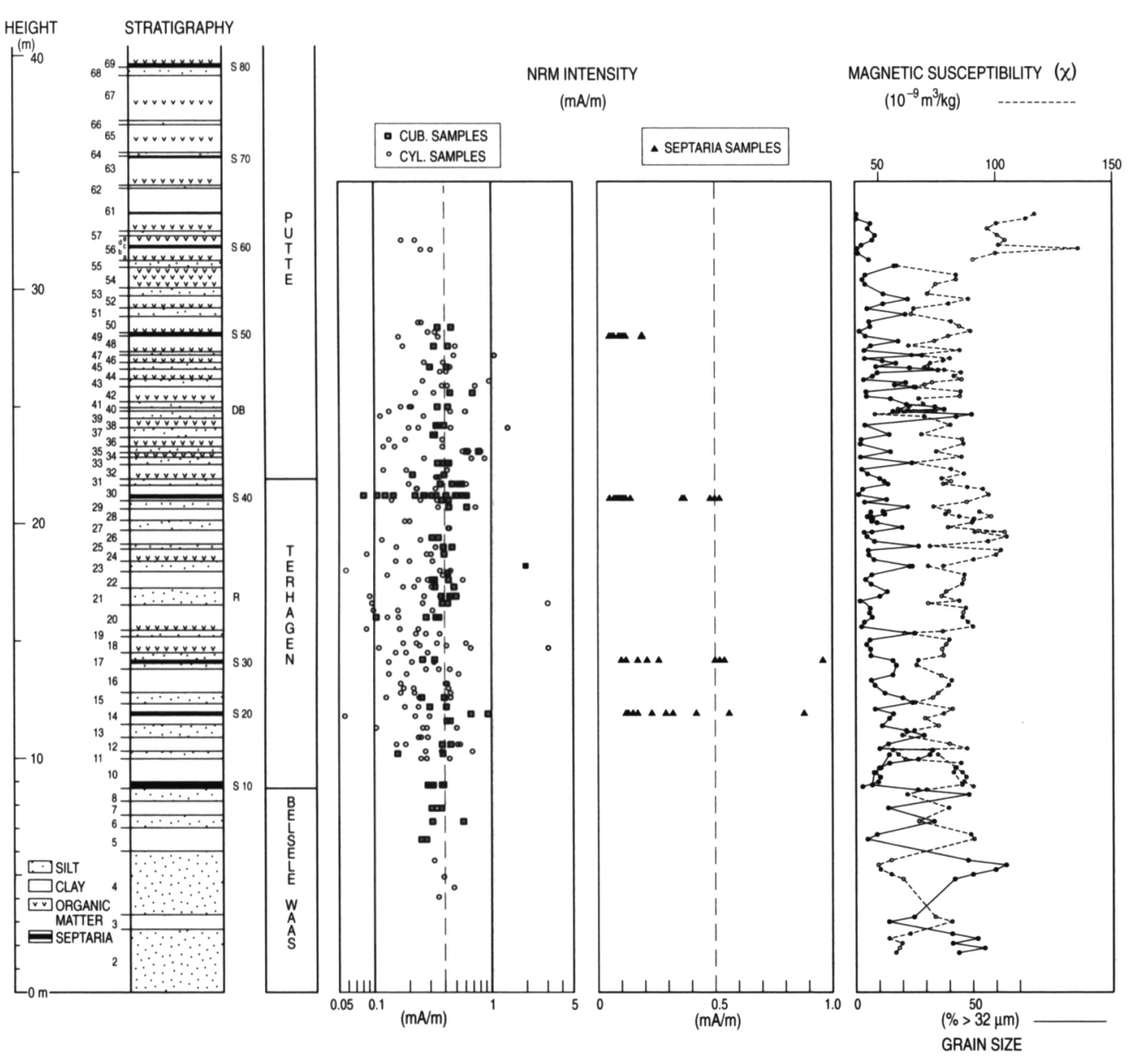

Fig. 4. NRM intensity plotted against the composite lithologic $\log$ of the outcrop area for clay, silt and septaria levels (S). At the right hand side the magnetic susceptibility and grain size for the clay and silt samples are plotted.
The average magnetic susceptibility $\chi$ is $79 \star 10^{-9}$ $\mathrm{m}^{3} / \mathrm{kg}$. Unlike the NRM intensity, a statistically significant negative correlation was found between $\chi$ and grain size, $\chi$ being higher in the clay compared to the silt layers (Fig. 4). The lowest average $\chi$ value corresponds to the Belsele-Waas Member, containing the thickest silt layers (Table 1). This correlation suggests that in the Boom Clay, $\chi$ is mainly controlled by the paramagnetic contribution of clay minerals, the relatively low NRM and $\chi$ values indicating a low magnetic content. This low ferrimagnetic mineral content may hamper isolation of the characteristic remanent magnetisation since the limiting signal-noise ratio of the magnetometer may be reached quickly during the stepwise demagnetisation.

\section{Alternating Field and Thermal Demagnetisation of the NRM}

Behaviour of the Boom Clay samples during stepwise a.f. demagnetisation is very diverse and often difficult to interpret. Demagnetisation could be grouped in 5 types (see further) (Fig. 5a to e). NRM intensity decreases below $20 \%$ at $10 \mathrm{mT}$ while, above $40 \mathrm{mT}$, spurious magnetisations are observed. This trend is an indication that in high alternating fields, artificial (spurious) magnetic remanences are induced in a rest field and/or that the magnetisation contains highly unstable components. No vector end point diagrams show linear segments, most probably an indication that the different components building up the NRM have overlapping coercivity spectra. A linear segment through the origin is never been observed, meaning that after demagnetisation at $40 \mathrm{mT}$ additional, different components are present or created in the signal.

In all, 90 samples were incrementally demagnetised at increasing temperatures (Fig. 5f). Experiments have shown that above $370^{\circ} \mathrm{C}$ the orientation of the magnetic remanence becomes erratic and that additional heating does not provide additional polarity information.

During thermal demagnetisation, an increase in the remanence signal is observed at about $270^{\circ} \mathrm{C}$, suggesting thermal induced mineral transformations. Indications of these transformations are also found in the thermomagnetic curves, as described in a further section.

Measured at room temperature, $\chi$ remains constant up to $320^{\circ} \mathrm{C}$ after each heating step followed by a marked increase starting at approximately 360 and up to $500-550^{\circ} \mathrm{C}$, and finally a strong decrease between 550 and $680^{\circ} \mathrm{C}$ (Fig. 6). The increase in susceptibility between 360 and $500^{\circ} \mathrm{C}$ can be explained in terms of 

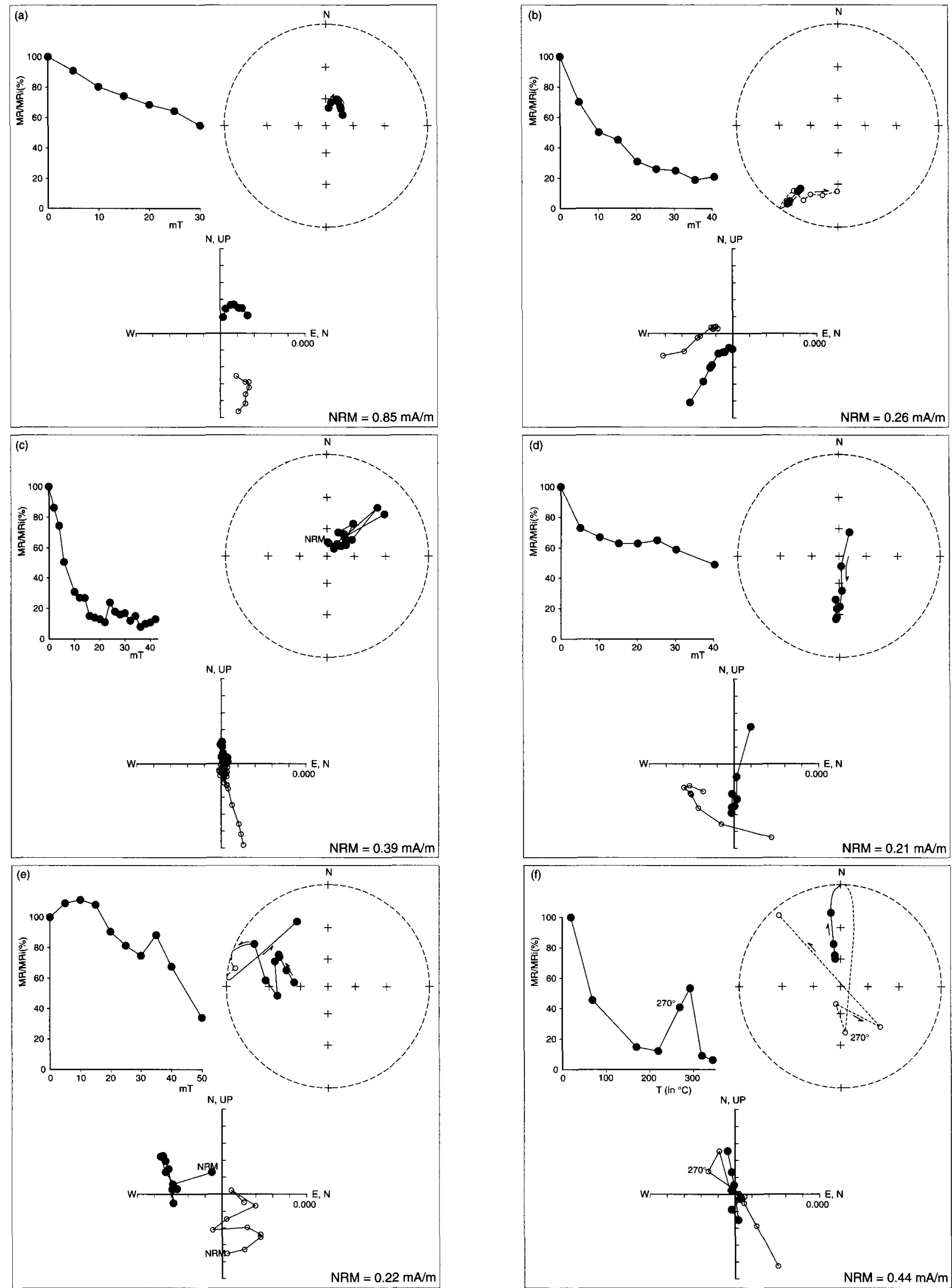

Fig. 5. Five examples of a.f. demagnetisation (a to e) and one thermal demagnetisation (f) with: (a) normal polarity (N!-class); (b) reverse polarity (R!-class); (c) doubtful normal polarity (N?-class); (d) doubtful reverse polarity (R?-class); (e) erratic behaviour (?-class) and (f) erratic behaviour (?-class). 


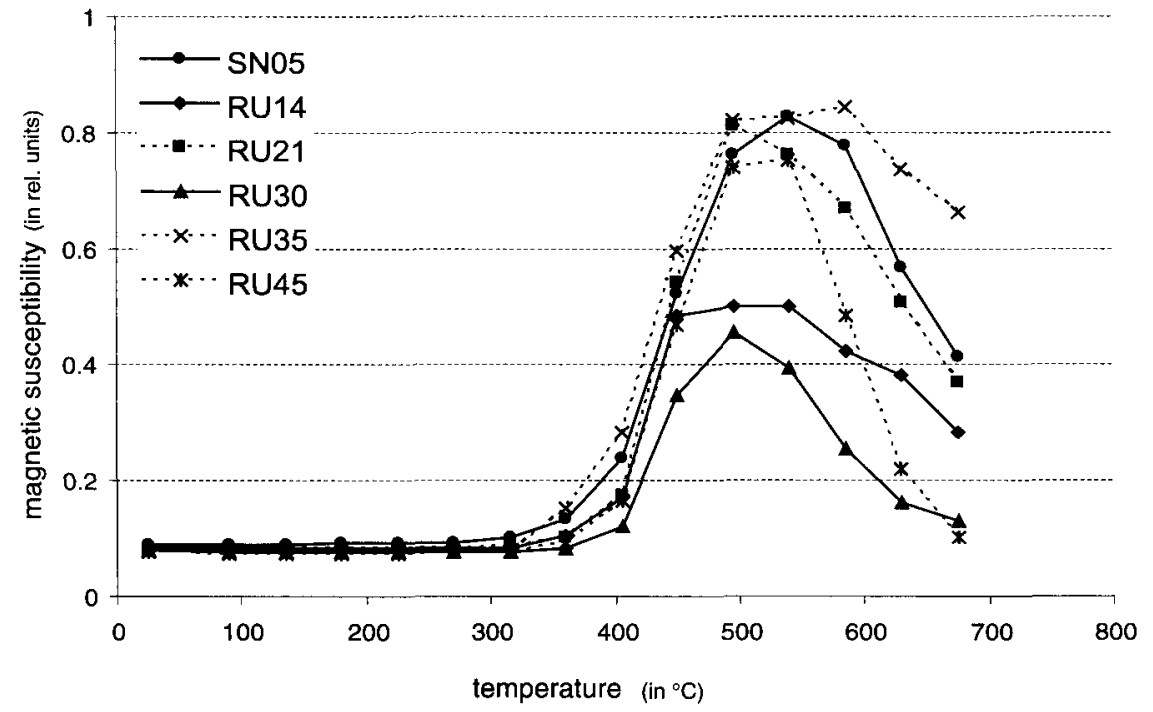

Fig. 6. Magnetic susceptibility changes during thermal demagnetisation of the NRM (the full lines are clay samples, the dotted lines silt samples). the thermally induced growth of magnetite through oxidation of pyrite. The strong decrease of susceptibility above $550^{\circ} \mathrm{C}$ can be attributed to further oxidation of magnetite into hematite.

\section{Acquisition of a viscous remanence during storage in the laboratory}

During storage in the laboratory, samples can acquire a viscous remanent magnetization (VRM) in the ambient magnetic field. Previous studies showed that this VRM can make up a major component of the magnetic signal in sediments (e.g. Prince et al., 1980) and that these remanences may be difficult to remove during the demagnetisation procedure. For the Boom Clay, the low NRM intensity may cause the VRM to influence the original NRM signal in such manner as to hamper the isolation of the primary magnetic component needed to determine the polarity of the NRM.
A storage test was applied to 34 samples collected over the entire section. The samples were prevented from drying out during the whole experiment. They were kept in the earth magnetic field successively orientated with $+\mathrm{X}$ towards north (during one month) and with $+\mathrm{X}$ towards south (one month) and afterwards in a zero field (for one week). After each handling, the remanent magnetisation of the samples was measured. The comparison of the stereographic projection of the orientation of the magnetic remanence vector during the north and south storage shows that the declinations turn to the south after rotation (Fig. 7). After the storage in the zero field the remanence direction is highly scattered and the magnetisation intensity lowered to about $50 \%$ of the initial value. The higher scatter and the decrease in intensity of the remanence show a randomising effect of the zero field on the parasitic magnetisation. Based on these results, samples were systematically stored for one week in a

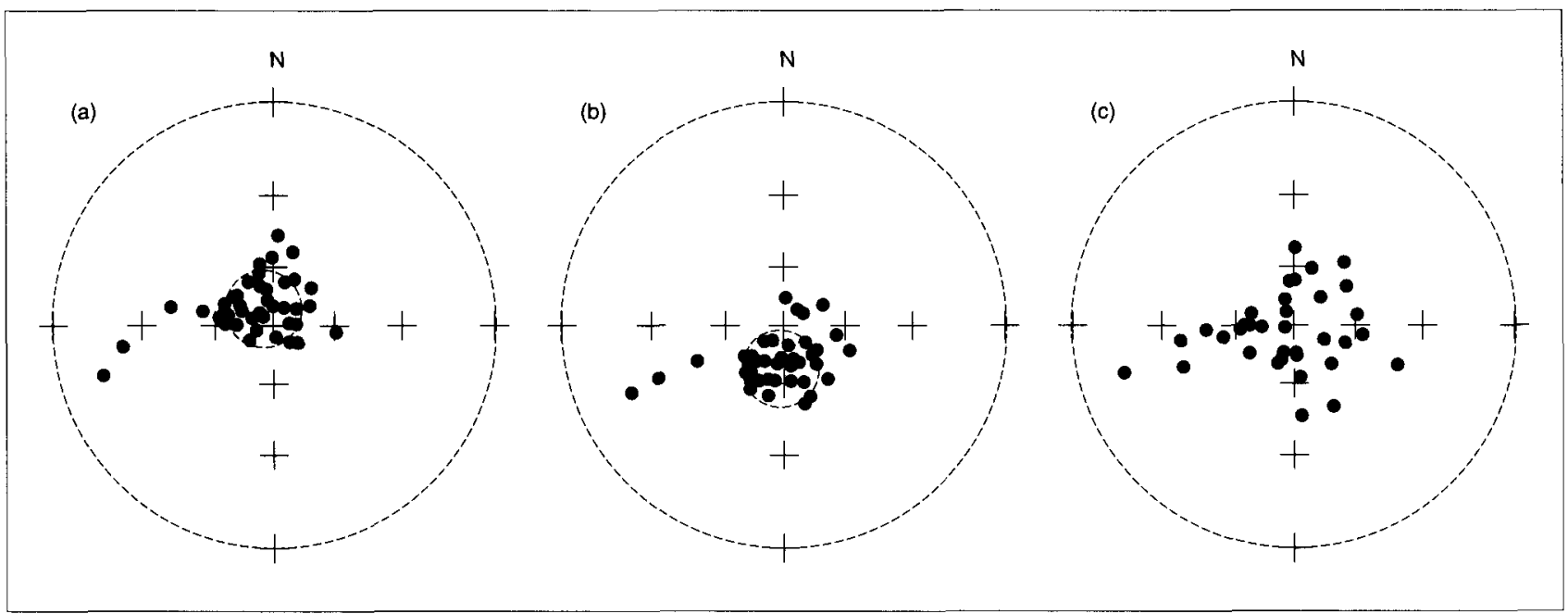

Fig. 7. Storage test: In the stereographic projection the samples were stored in the laboratory oriented to the magnetic north for one month (a). The samples were turned $180^{\circ}$ and after one month they were measured again (b). After this, the samples were stored in a controlled zero magnetic field and measured after one week (c). 
controlled zero magnetic field before starting the standard demagnetisation procedure.

In addition to the VRM, many of the dried samples showed signs of desiccation and shrinkage, even though they had been refrigerated and kept wrapped in plastic foil. To minimize this from occurring, the zero magnetic field storage and subsequent demagnetisation of the samples were carried out within a few days of sampling.

\section{Rock magnetic study of the septarian carbonate concretions}

Septaria are calcareous concretions occurring in specific layers that represent original marly sedimentation horizons that are modified by later diagenesis (Vandenberghe \& Laga, 1986; De Craen et al., 1999). Because of the early diagenetic formation of the septaria (Laenen \& De Craen, 2004), we examined the magnetic orientation for comparison. It is thought the NRM is locked in shortly after septaria formation and that a more stable magnetic signal may be preserved than in the clay and silt. Unfortunately, septaria are characterised by low NRM intensities and their behaviour during a.f. and thermal demagnetisation was unstable and erratic. The room temperature $\chi$ measured after each heating step shows the same increase in intensity as for the clay and silt samples. Conversely, the decrease above the $550^{\circ} \mathrm{C}$ point seen in the clay and silt samples is not observed in the septaria. This is because the further oxidation of newly formed magnetite to hematite does not happen, perhaps caused by the lower permeability of oxygen in the hard-rock septaria texture as compared to the soft clay and silt samples. The paleomagnetic study of the septaria has shown that no reliable information can be gathered from them.

\section{Magnetomineralogy}

The identification of the magnetic remanence carriers and minerals that had an influence on the remanence carriers in the sediment, may provide information about the timing and mechanism of the remanence acquisition process (chemical RM, detrital RM and viscous $R M$ ). If these carriers and their grain size are known, the thermal demagnetisation procedure can be focussed on the interval where these minerals would unblock. Thus, knowledge of the magnetomineralogy may increase the reliability of the magnetostratigraphic interpretations.

The number of magnetic minerals that occur in nature is not large (Dekkers, 1997). Because of the reducing environment in the Boom Clay Formation (organic rich and abundant pyrite), the number of potential remanence carriers is limited. Both hematite, iron oxide in the most oxidised form, and goethite, the iron hydroxide, are not stable under reducing conditions and thus unlikely as a potential remanence carrier. The presence of abundant pyrite ( 0.66 to $3.75 \%$, Laenen, private communication, 2002); however, is of great importance for the magnetic properties of the sediment. Pyrite is an authigenic mineral which forms during early diagenesis in organic rich sediments, involving bacterial sulphate reduction (Berner, 1984). On the one hand, these reactions lead to dissolution of the detrital iron oxides, such as magnetite and hematite, thereby lowering or completely erasing the original magnetisation of the sediment. On the other hand, ferrimagnetic minerals can be formed by this process because the initial product of the iron sulphide formation is not pyrite but a series of metastable phases, like the ferrimagnetic minerals greigite and pyrrhotite. If they are preserved even in small quantities in the sediment they can contribute to the magnetic remanence.

Therefore, the subsequent magnetomineralogical investigation focused on establishing the eventual presence of magnetite, from detrital or biogenic origin, and authigenic iron sulphides.

\section{Thermal demagnetisation of the isothermal remanent magnetisation}

Because of the low intensities of the NRM and the occurrence of spurious magnetisations, it is difficult to interpret the thermal decay of the NRM in terms of magnetic remanence carriers. To increase the remanent magnetisation, an external magnetic field was applied on two samples. The breakdown of this magnetic remanence by thermal demagnetisation can give a clearer interpretation of the ferromagnetic content of the rock (Lowrie, 1990).

The Lowrie test was applied to a silt sample (layer 35) and a sample from the R-band (the silty red layer 21, Fig. 2). An IRM was given along three perpendicular directions: the $\mathrm{Z}$-axis at $0.95 \mathrm{~T}$, the $\mathrm{Y}$-axis at $0.4 \mathrm{~T}$, and the $\mathrm{X}$-axis at $0.05 \mathrm{~T}$. The thermal demagnetisation in air of the three IRMs first sample (Fig. 8a) shows that most of the remanence is held by a soft to medium blocking temperature fraction. The contribution of the hard fraction is negligible. An initial, sharp drop in the intensity is observed between 300 and $360^{\circ} \mathrm{C}$. After this point, the decay occurs in a nearly linear direction to $600^{\circ} \mathrm{C}$. At the other sample (Fig. 8b), from the R-band, the contribution of the hard fraction as well as the magnetisation is higher. Two maximum unblocking temperature $(\mathrm{Tb})$ components can be 

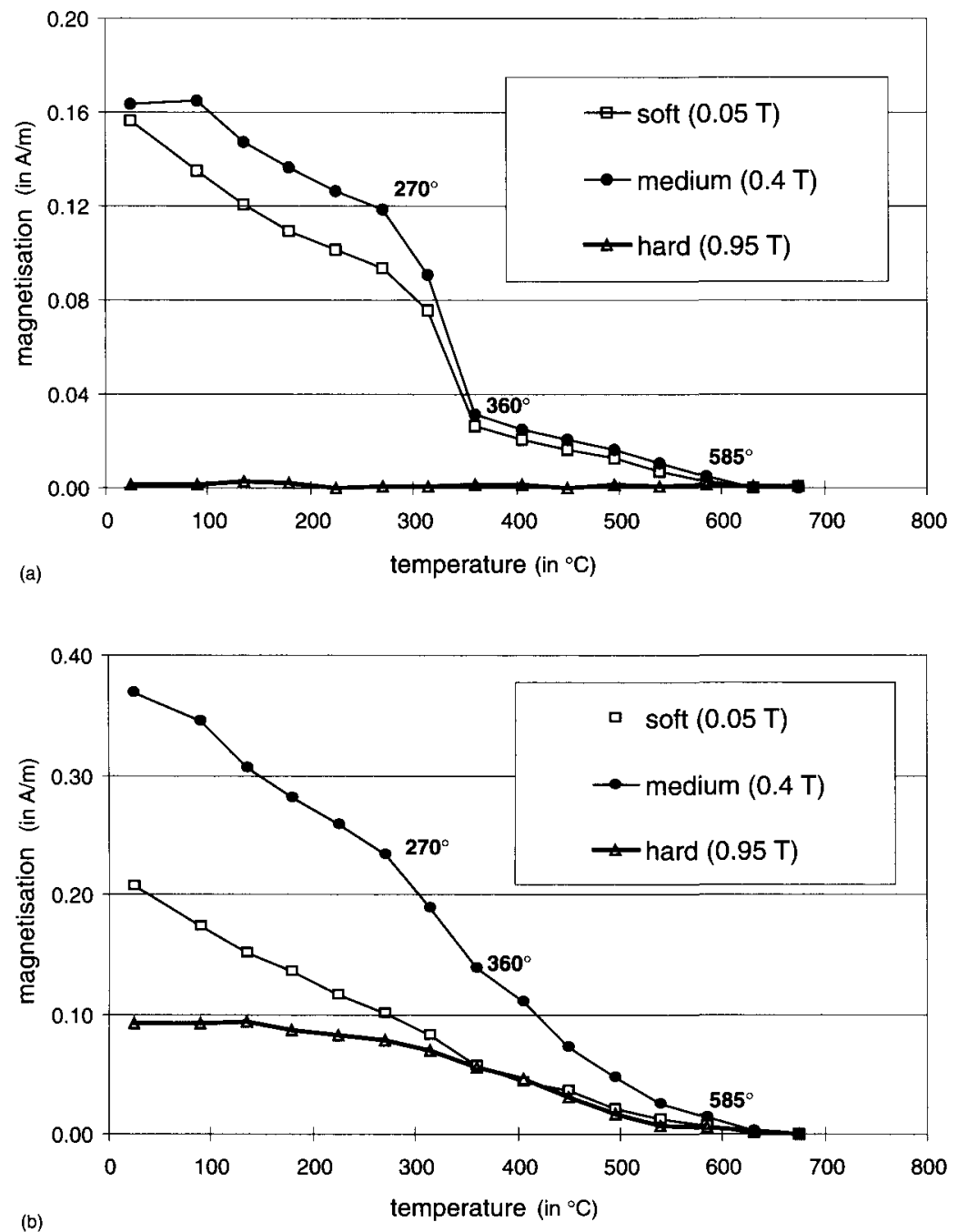

Fig. 8. Thermal demagnetisation of a three-component IRM produced by magnetising the samples in $0.95 \mathrm{~T}$ along its $\mathrm{Z}$-axis, followed by $0.4 \mathrm{~T}$ along the $\mathrm{Y}$-axis, and finally $0.05 \mathrm{~T}$ along the $\mathrm{x}$-axis. (a) sample of silt layer 35 and (b) sample of the layer 21 (R-band). recognised: a low temperature (LT) component with a Tb between 270 and $360^{\circ} \mathrm{C}$ and (2) a high temperature (HT) component with a $\mathrm{Tb}$ of $585^{\circ} \mathrm{C}$ up to $640^{\circ} \mathrm{C}$.

\section{Thermomagnetic curve}

A powerful technique to gather information about the presence of magnetic minerals is the acquisition of thermomagnetic curves. In these experiments, the magnetic moment is determined as a function of the temperature. The aim of the measurement is to determine the Curie temperature ( $\mathrm{Tc}$ ) of the magnetic minerals and to distinguish between chemical alteration and thermal demagnetisation of the remanence carriers. The amount of magnetic minerals appeared to be very low, a confirmation of the low NRM signal (Fig. 9). The $450^{\circ} \mathrm{C}$ run shows the expected increase of ferromagnetic magnetisation due to the formation of the strongly magnetic magnetite through the oxidition of pyrite. After heating at $350^{\circ} \mathrm{C}$, the cooling curve is slightly below the heating curve, perhaps pointing to the presence of a magnetic iron sulphide (like greigite or pyrrhotite). However, there is no direct indication of this mineral either in the Tc or the characteristic thermal alteration reactions.

\section{Magnetic mineral extraction and identification}

Because of the low concentration of the magnetic minerals in the bulk samples, magnetic extraction and concentration were carried out on the clay layer 30 and the silt layer 33 (Fig. 2). The $>500 \mu \mathrm{m}$ fraction consists of pyrite grains up to a few centimetres in diameter. XRD of these crushed nodules only revealed a pyrite composition.

Table 2 gives an overview of the minerals after wet magnetic extractions. XRD examinations of the magnetic concentrates revealed the presence of quartz, chlorite and pyrite. With the SEM, the presence of large amounts of pyrite and minor amounts of chromite, ilmenite and rutile could be identified. The optical reflected light microscopy and microprobe analysis revealed pyrite, chromite, ilmenite, rutile and a single grain with a $\mathrm{Fe}_{2} \mathrm{TiO}_{5}-\mathrm{FeTi}_{2} \mathrm{O}_{5}$ (ferro-pseudobrookiet - pseudobrookiet) composition (Table 2). 
Table 2. An overview of the minerals found with the mineralogical techniques.

\begin{tabular}{lccccc}
\hline & Pyrite & Chromite & Imenite & $\begin{array}{l}\mathbf{F e}_{2} \mathbf{T i O}_{5} \\
-\mathbf{F e T i}_{2} \mathbf{O}_{5}\end{array}$ & $\begin{array}{l}\text { Rutile } \\
\mathbf{Q} \\
\text { (+fsp) } \\
\text { (illite, glauconite) }\end{array}$ \\
$\begin{array}{l}\text { SEM } \\
\text { Reflected microscopy } \\
+ \text { microprobe analysis }\end{array}$ & $\bullet$ & $\bullet$ & $\bullet$ & $\bullet$ \\
\hline
\end{tabular}
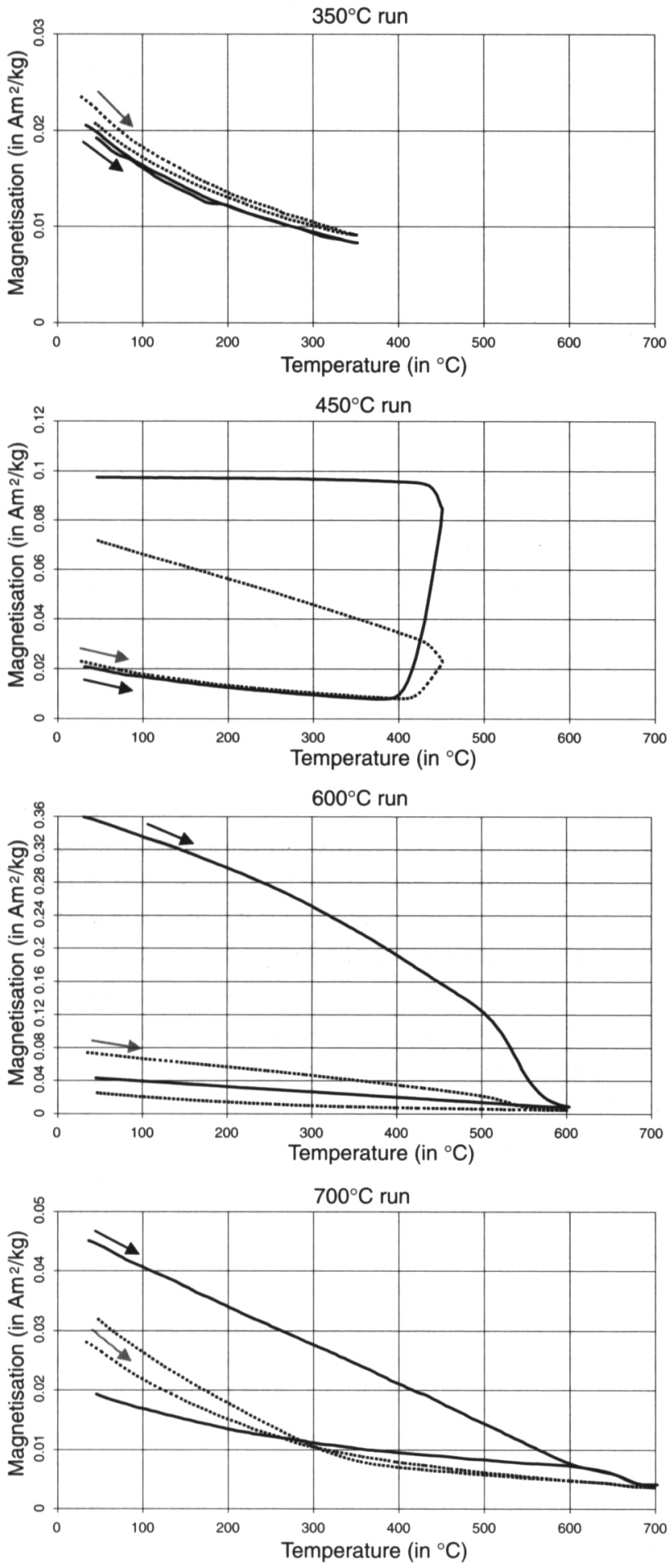

Fig. 9. Thermomagnetic measurements on a sample of layer 30 (full line) and layer 32 (dotted line). The heating curve is indicated with the arrow. The chemical reactions due to oxidation occur above $410^{\circ} \mathrm{C}$.

\section{Discussion of the magnetomineralogy}

The thermal demagnetisation of the laboratory induced IRM gives two maximum Tb-components: 1. a low temperature (LT)-component with a maximum $\mathrm{Tb}$-component between 270 and $360^{\circ} \mathrm{C}$; and 2 . a high temperature (HT)-component with a maximum $\mathrm{Tb}$ of $585^{\circ} \mathrm{C}$. Thermomagnetic measurements indicated the presence of a remanence carrier in the $350^{\circ} \mathrm{C}$ run, but the concentration was too low to identify it on the basis of a Tc or characteristic transformation behaviour.

1. Regarding the LT component, a similar component has been previously recognised in several paleomagnetic studies and is possibly attributed to magnetic iron sulphides (Snowball \& Thompson, 1990; Zijderveld et al., 1991; Van Hoof \& Langereis, 1991; Roberts \& Turner, 1993; Mary et al., 1993; Van Velzen et al., 1993; Reynolds et al., 1994; Snowball, 1994; Florindo \& Sagnotti, 1995; Roberts, 1995; Thompson \& Cameron, 1995). The magnetic iron sulphides greigite and pyrrhotite both have a Tc that can be responsible for magnetic remanence in the temperature interval of the LT-component. Distinguishing between greigite and pyrrhotite is difficult because they have a similar chemical composition and only a small difference in Tc. This is the reason why the magnetic iron sulphides are often not further specified (Zijderveld et al., 1991; Van Hoof \& Langereis, 1991; Van Velzen et al., 1993). Greigite has been increasingly documented in a wide variety of sediments and soils (Reynolds, 1994; Roberts, 1995).

2. Regarding Tb-spectra of the HT-component, these is an indication for the presence of magnetite with a $\mathrm{Tc}$ of $585^{\circ} \mathrm{C}$. The orientation of the laboratory induced magnetisations is stable below this temperature and becomes erratic above $585^{\circ} \mathrm{C}$, the $\mathrm{Tc}$ of magnetite, which is an additional indication for the contribution of magnetite.

However, the magnetic iron sulphides and magnetite assumed through the magnetic techniques, could not be found with the different mineralogical techniques applied to the magnetic extractions. The reason might be due to the low concentration of these minerals, the small grain size, and the close physical relation with pyrite. 


\section{Magnetostratigraphy}

\section{Polarity classification of the outcrop}

The entire demagnetisation data set (298 measurements) was classified according to reliability in trend direction classes.

A distinction was made following the classification described in Ali et al. (1993). A stable end point (SEP) direction is obtained during the demagnetisation process, when the effect of any low coercivity secondary magnetisation can be completely removed from the specimen. In fact, this occurs when there is not a completely overlapping coercive spectra of primary and secondary magnetisations. In this case, when only two components are present, the specimen remanence direction remains unchanged above a certain demagnetisation step. Beyond this step, the only property affected by continued demagnetisation is the steady decay of the intensity. Specimens included in the trend direction class do not show a SEP direction, indicating that the stable or characteristic remanent magnetisation is not completely isolated. Nevertheless, the data from 'trending' specimens can still be reliably used in polarity determination if the trend is toward a normal or reverse polarity direction. The term erratic direction is used to classify remanence data, showing great fluctuations in both directions and intensity. This condition is most commonly encountered in weakly magnetic specimens, for which the signal to noise ratio approaches one during demagnetisation in low a.f.'s.

No clear SEP directions were reached for the Boom Clay and only trend and erratic directions could be recognised. The demagnetisation data were divided in five classes: N!, N?, R!, R? and ? (Fig. 10). From the specimens belonging to classes $N$ ! and $R$ ! a polarity

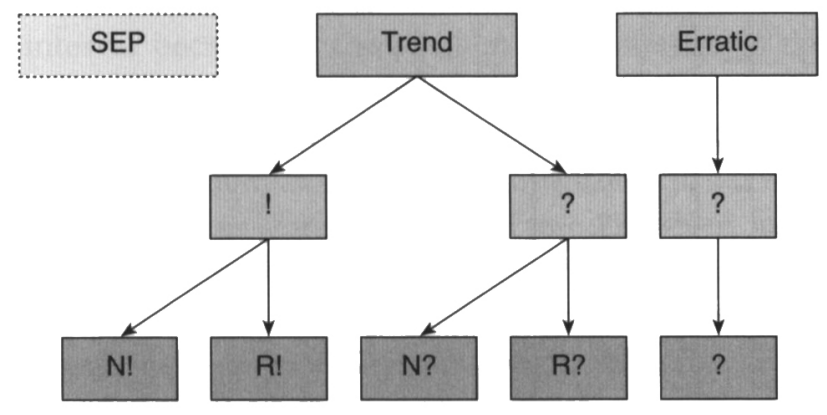

Fig. 10. Polarity classification: Stable end point directions (SEP) are not present in the demagnetisation data of the Boom Clay, only trend and erratic directions could be recognised. The trend samples are subdivided in two classes: the reliable (!) and less reliable (?) measurements, with each a normal $(\mathbf{N})$ and a reversed (R) class. The samples without a polarity determination are divided in the ?-class. determination was made according to a trend toward a normal $(N)$ or reverse $(R)$ polarity. During the demagnetisation procedure a consistent directional change in orientation of the magnetisation can be recognised but a final end direction is not reached (Fig. $5 a$ and b). Likewise for the $\mathrm{N}$ ? and R?-classes, a directional change of the magnetisation vector is observed during the successive demagnetisation steps in low a.f's, but the magnetisation quickly becomes unstable resulting in large directional fluctuations. The samples of the classes N? and R? can supply support or throw doubt upon a polarity determination.

The data in the ?-class corresponds to erratic class of Ali et al. (1993) for which no polarity determination could be made. About one third of the data set belongs to the $\mathrm{N}$ ! or $\mathrm{R}$ ! classes, one fifth is $\mathrm{N}$ ? or $\mathrm{R}$ ? and about half of all data is 'erratic' (?-class) (Table 3).

\section{Magnetostratigraphic interpretation}

Polarity determinations are plotted against the lithostratigraphic column in Fig. 11. It can be seen that there is a dominant abundance of normal polarities in the Putte Member and a dominant abundance of reversed polarities in the Terhagen and Belsele-Waas Members. The normal polarity interval in the Putte Member is interrupted by two undetermined zones (hatched). Thus, five polarity intervals are distinguished.

Interval 1 , from the highest sample in the section to the centre of layer 50 , exhibits the first predominantly normal interval at the top of the section. The relative low portion of useful polarity determinations and the absence of a second confirming sample, established the point at which this interval was split from the lower normal polarity interval 2 .

Interval 2, from the centre of layer 50 to the base of layer 42 , is clearly dominated by normal polarities. One $R$ ! polarity is measured in the same level where two N!-determinations are present. This level is; however, surrounded by a convincing amount of normal polarities.

Table 3. Reliability classification of the entire demagnetisation data set used to draw up the magnetostratigraphy of the Boom Clay in the type section (percentage between brackets).

\begin{tabular}{lllr}
\hline Polarity & $!$ & $?$ & \multicolumn{1}{l}{ Total } \\
\hline $\mathrm{N}$ & $49(16.4)$ & $20(6.7)$ & $69(23.2)$ \\
$\mathrm{R}$ & $47(14.8)$ & $39(13.1)$ & $83(27.9)$ \\
Subtotal & $96(31.2)$ & $59(19.8)$ & $152(51.0)$ \\
$?$ & & & $146(49.0)$ \\
Total & & & $298(100)$ \\
\hline
\end{tabular}


Interval 3, from the base of layer 42 to the top of layer 38 , is defined by an undetermined (hatched) zone that interrupts the normal polarity interval. In two levels, a R! and a N!-determination are present.

Interval 4, from the top of layer 38 to the base of layer 31 , is identified by a clearly dominant normal polarity zone with a complete absence of R!-determinations.

Interval 5, from the base of layer 31 to the lowest sample of the section, is classified in one thick reversed polarity zone, interrupted by two short normal levels (drawn in on the basis of two $\mathrm{N}$ !-determinations).

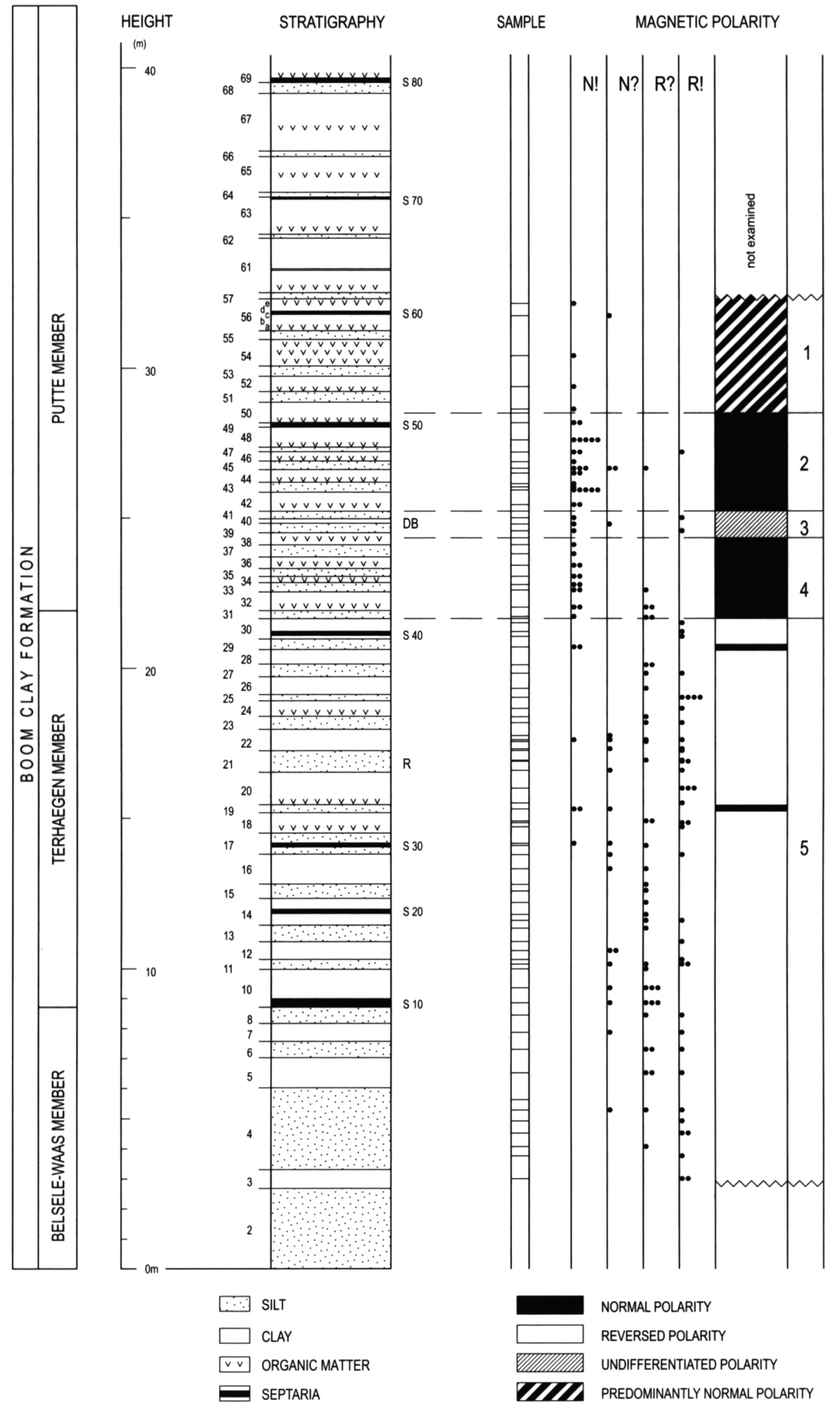

Fig. 11. Polarity classification of the polarity measurements plotted against the composite lithologic log of the type section of the Boom Clay. 5 polarity intervals are distinguished (numbers 1 to 5 ). 
The most striking feature of the magnetostratigraphic zonation of the Boom Clay in the outcrop area is a predominantly normal interval at the top of the section (subdivided in intervals 1 to 4 ) that coincides almost entirely with the Putte Member and the relatively long reversed polarity interval (5) at the base, virtually coinciding with the Terhagen and BelseleWaas Members. The correlation with the standard polarity time scale (GPTS95 in Berggren et al., 1995) will be focused on the boundary between the predominantly normal and reversed polarity interval.

Only when the biostratigraphic data of the Boom Clay Formation provides a high chronostratigraphic resolution, the observed $\mathrm{R} / \mathrm{N}$ reversal can be identified. When this can be done, the $\mathrm{R} / \mathrm{N}$ reversal, in turn, may refine the chronostratigraphic dating of the section.

The Boom Clay Formation, the unit stratotype of the Rupelian Stage, has been the topic of many macro- and micropaleontological studies. Planktonic foraminifera, nannoplankton, and especially organic walled dinoflagellate cysts (dinocysts) allow correlation with the integrated magnetobiochronologic time scale (Berggren et al., 1995). Planktonic foraminifera of several outcrop sections and boreholes throughout the Rupelian stratotype were investigated by Hooyberghs $(1983,1992)$. According to this author, the Boom Clay Formation comprises planktonic foraminiferal zones P18-P21 of Blow (1979). However, no zonal boundaries could be identified since some of the zonal markers were not encountered or had a peculiar range. The unusual and diachronous range of several marker species is most likely due to major differences in paleolatitude and paleobiogeography during the Early Oligocene between the tropics and the restricted North Sea Basin (Poore et al., 1982; Wei \&Wise, 1989). Moreover, planktonic foraminifers in the North Sea Basin are rather rare for this timeinterval because of the semi-enclosed nature of the basin with only narrow inlets to the northwest and the southeast. These problems urged Hooyberghs (private communication, 2002) to use substitutes to identify the planktonic foraminiferal zones. However, until now, the application and validity of these substitutes in the international magnetobiochronologic time scale (Berggren et al., 1995) is not well understood. Since the identification of the observed R/N reversal in the Boom Clay Formation is only served with accurate and high resolution biostratigraphic data, the planktonic foraminiferal data by Hooyberghs (1983, 1992) could not be used.

Detailed nannoplankton analysis (Steurbaut, 1986, 1992) revealed that the boundary between Martini's nannoplankton zones NP22/NP23 is situated in the upper part of the Ruisbroek Sands; approximately $1 \mathrm{~m}$ below the base of the Boom Clay Formation (Fig. 12). Recent studies on both the outcrop area as well on boreholes (Van Simaeys et al., 2004) showed that the entire outcrop section belongs to nannoplankton zone NP23. The boundary between Martini's nannoplankton zones NP23 and NP24 was found higher up the Boom Clay Formation (only known from boreholes in northeast Belgium). However, the latter could only be identified by using a substitute species because the zonal marker for the base of Martini's nannoplankton zone NP24 (Sphenolithus ciperoensis) is absent in the Boom Clay Formation (Van Simaeys et al., 2004). Since the studied outcrop section can be attributed to Martini's nannoplankton zone NP23, only two candidates remain to identify the observed $\mathrm{R} / \mathrm{N}$ reversal; namely $\mathrm{C} 12 \mathrm{r} / \mathrm{C} 12 \mathrm{n}$ and $\mathrm{C} 11 \mathrm{r} / \mathrm{C} 11 \mathrm{n} .2 \mathrm{n}$. A more precise determination based on calcareous nannoplankton is not possible.

Dinocysts seem to be less affected by latitudinal variations and occur in shallow as well as in deep marine settings. The widespread distribution of dinocysts avoids using substitutes and therefore allows detailed interregional correlations. Both the outcrop sections as well as the younger part of the Boom Clay Formation, only known from boreholes in northeastern Belgium, were subjected to a detailed dinocyst analysis (Stover \& Hardenbol 1994; Van Simaeys et al., 2004). These studies revealed that the boundary between dinocyst zone D14na and D14nb coincides with a level between Septaria Horizon $S 100$ and $S 110$, based on the last occurrence (LO) of Enneadocysta pectiniformis. The LO of this species is dated at 29.3 million years (Ma) for Northern Hemisphere Mid Latitudes (Hardenbol et al., 1998; Williams et al., 2004). The LO of Enneadocysta pectiniformis in the Boom Clay Formation virtually coincides with the first occurrence (FO) of Saturnodinium pansum; the FO of the latter species is believed to have an appropriate age of $29.4 \mathrm{Ma}$ (Williams et al., 2004). The LO of Enneadocysta pectiniformis and the FO of Saturnodinium pansum occur at the base of magnetochron C10r (= 29.4 Ma in Berggren et al., 1995) (Fig. 12). The LO of Phthanoperidinium filigranum coincides with a level between Septaria Horizon S50 and S60 in the outcrop section. According to Hardenbol et al. (1998) this event occurs at the top of magnetochron $\mathrm{C} 12 \mathrm{n}$ and is dated at $30.5 \mathrm{Ma}$. The LO of Corrudinium incompositum virtually coincides with Septaria Horizon S-40 in the outcrop section (Stover \& Hardenbol, 1994). Based on well-calibrated sections all over the world, the LO of this species is dated at 31.3 Ma (Hardenbol et al., 1998; Williams et 


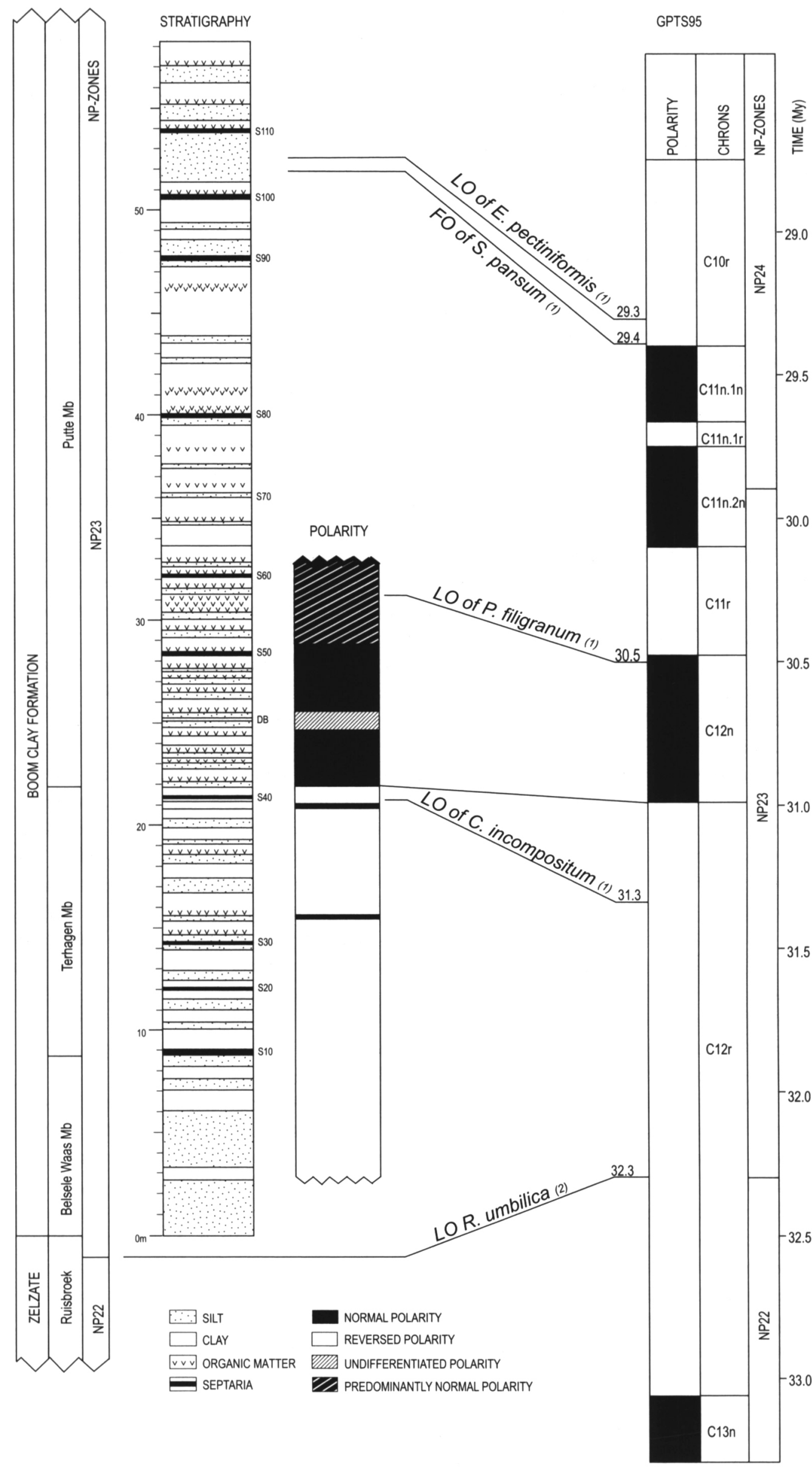

Fig. 12. Correlation between the outcrop section of the Boom Clay Formation and the magnetobiochronologic time scale (after Berggren et al., 1995). Absolute age of dinocyst events (1) after Hardenbol et al., 1998 and Williams et al., 2004; absolute age of nannoplankton events (2) after Hardenbol et al., 1998. Dinocyst events after Stover \& Hardenbol, 1994 and Van Simaeys et al., 2004. The $\mathrm{R} / \mathrm{N}$ reversal in the outcrop area correlates with the $\mathrm{C} 12 \mathrm{R} / \mathrm{C} 12 \mathrm{~N}$ reversal. 
al., 2004) and thus correlates with a level at the top of magnetochron C12r (Fig. 12).

By integrating both nannoplankton and dinocyst data, it is clear that the observed $R / N$ reversal in the Boom Clay Formation can only be attributed to the $\mathrm{C} 12 \mathrm{r} / \mathrm{C} 12 \mathrm{n}$ reversal which has an appropriate age of $30.95 \mathrm{Ma}$ in the international magnetobiochronologic time scale of Berggren et al. (1995). Correlations based on dinocysts revealed that polarity intervals 1 to 4 belong to magnetochron $\mathrm{C} 12 \mathrm{n}$ while polarity interval 5 belongs to magnetochron C12r (Figs 11 and 12). Based on the LO of Enneadocysta pectiniformis and the FO of Saturnodinium pansum between Septaria Horizons S100 and S1 10 in the Boom Clay Formation, this level can be correlated with the base of magnetochron C10n. This implies, although no magnetostratigraphic data available, that the interval between Septaria Horizons S60 and S100 would correlate with magnetochron $\mathrm{C} 11 \mathrm{r}$ and $\mathrm{C} 11 \mathrm{n}$ (Fig. 12).

The boundary between the predominantly normal (interval 1 to 4) and reverse (interval 5) magnetozones virtually coincides with the boundary between the grey coloured Terhagen Member and the dark coloured Putte Member. This could suggest that the position of the magnetozone boundary is possibly influenced by secondary processes modifying the acquired NRM. However, the position of the lithological boundary (base of layer 32) differs from the position of the magnetozone boundary (base of layer 31); this difference suggests that the magnetozone boundary is indeed reliable.

The two short normal polarity intervals in polarity interval 5, drawn on the basis of 2 normal polarity measurements in the type section, are not present in magnetochron C12n of the GPTS95. This simply can be explained by the fact that polarity intervals shorter than $30 \mathrm{ky}$ are not incorporated in the GPTS95 (Berggren et al., 1995). The existence of short polarity intervals remains a moot point as it is not clear whether they represent true reversals or strong lowerings of the magnetic intensity (Cande \& Kent, 1992; Hartl et al., 1993; Lowrie \& Lanci, 1994).

\section{Magnetostratigraphy of two cored wells in the Boom Clay as comparison}

For comparison and confirmation of the magnetostratigraphic boundary recognised in the outcrop area, the Boom Clay Formation was sampled in two cored wells in the north of Belgium (Mol-1 and Zoersel, Fig. 1) and paleomagnetically investigated. As the Cenozoic sediments in the north of Belgium are slightly dipping to the north, the Boom Clay is covered by younger sediments and the Boom Clay itself is about $70 \mathrm{~m}$ thicker than in the outcrop area.
Because of the lack of an azimuth orientation of the cores, the magnetic declination could not be deduced. A magnetic reorientation of the cores was not possible because of the weak and diverse NRM signal. This shortage in magnetic orientation prohibits the use of the magnetostratigraphy of the cored wells.

\section{Conclusions}

1. This study presents both magnetostratigraphy and the newest biostratigraphic findings of the Rupelian unit-stratotype in northwest Belgium. By integrating both nannoplankton and dinocyst data, it is clear that the observed $\mathrm{R} / \mathrm{N}$ reversal can be attributed to the $\mathrm{C} 12 \mathrm{r} / \mathrm{C} 12 \mathrm{n}$ reversal with an appropriate age of $30.95 \mathrm{Ma}$ according to the international magnetobiochronologic time scale of Berggren et al. (1995).

2. The rock magnetic study points to magnetite as most important remanence carrier in the Boom Clay. Indications of the presence of magnetic iron sulphides are found.

3. During thermal treatment in air the iron bearing minerals of the Boom Clay (sulphides) oxidise into magnetite.

4. Strong negative correlation between grain size and magnetic susceptibility suggests that in the Boom Clay $\chi$ is mainly controlled by the abundance of the clay minerals.

5. On the basis of the experiences of this study the following recommendations can be made: a. Store samples in a zero magnetic field for one week in advance before measuring the magnetic polarity in order to lower the VRM. b. Limit the number of heating-cooling cycles during THDEM, as mineralogical transformations (especially pyrite oxidation) may already start at low temperatures $\left(<220^{\circ} \mathrm{C}\right)$. c. Use of the cube sampling technique in sediments, especially in clayey horizons, is preferential over the cylindrical technique as it induces fewer disturbances.

6. The paleomagnetic investigation of two cored wells revealed to be unsuitable to draw up a magnetostratigraphy because they were based only on magnetic inclination.

\section{Acknowledgments}

M.J. Dekkers of the Paleomagnetic Laboratory 'Fort Hoofddijk' of the University of Utrecht (The Netherlands) is thanked for measuring the thermomagnetic curves. The quarry owners (Swenden N.V., Heylen, Gralex N.V. and Scheerders van Kerckhove) of the Boom Clay and the Belgian Nuclear Research Centre (SCK-CEN) are thanked for the permission to sample 
respectively the clay pits and the two cored wells. Part of the research is sponsored by the Fund for Scientific Research - Flanders (F.W.O. G.0093.01N/E8).

\section{References}

Ali, J.R., King, C. \& Hailwood, E.A., 1993. Magnetostratigraphic calibration of early Eocene depositional sequences in the southern North sea basin. In: Hailwood, E.A. \& Kidd, R.B. (eds): High Resolution Stratigraphy, Geological Society London Special Publication 70 (London): 99-125.

Berggren, W.A., Kent, D.V., Swisher, III, C.C. \& Aubry, M.-P., 1995. A revised Cenozoic Geochronology and Chronostratigraphy. In: Berggren, W.A., Kent, D.V., Aubry, M-P. \& Hardenbol, J. (eds): Geochronology, Time Scales and Global Stratigraphic Correlation, Society for Sedimentary Geology (SEPM), Special Publication 54: 129-212.

Berner, R.A., 1984. Sedimentary pyrite formation: An update. Geochimica et Cosmochimica Acta 48: 605-615.

Blow, W.H., 1979. The Cainozoic Globigerinida (3 volumes). Brill: $1412 \mathrm{pp}$.

Cande, S.C. \& Kent, D.V., 1992. A new geomagnetic polarity time scale of the Late Cretaceous and Cenozoic. Journal of Geophysical Research 97: 13917-13951.

De Craen, M., Swennen R. \& Keppens, E., 1999. Petrography and geochemistry of septarian carbonate concretions from the Boom Clay Formation (Oligocene, Belgium). Geologie en Mijnbouw 77: 63-76.

Dekkers, M.J., 1989. Magnetic properties of natural pyrrhotite part II: High- and low-temperature behaviour of Jrs and TRM as function of grain size. Physics of the Earth and Planetary Interiors 57: 266-283.

Dekkers, M.J., 1997. Environmental magnetism: an introduction. Geologie en Mijnbouw 76: 163-182.

Florindo, F. \& Sagnotti, L., 1995. Palaeomagnetism and rock magnetism in the upper Pliocene Valle Ricca (Rome, Italy). Geophysical Journal International 123: 340-354.

Hailwood, E.A. \& Ting, F., 1990. Preliminary magnetostratigraphic investigations of the Oligocene Boom Clay (Belgium) and Bovey Beds (UK). Tertiary Research 11: 209.

Haq, B.U., Hardenbol, J. \& Vail, P.R., 1987. Chronology of fluctuating sea level since the Triassic. Science 235: 1156-1167.

Hardenbol, J., Thierry, J., Farley, M.B., Jacquin, T., de Graciansky, P.C. \& Vail, P., 1998. Mesozoic and Cenozoic sequence chronostratigraphic framework of European Basins. In: Graciansky, P.C., Hardenbol, J., Jacquin, T. \& Vail, P.R. (eds): Mesozoic and Cenozoic Sequence Stratigraphy of European Basins, Society for Sedimentary Geology (SEPM), Special Publication 60: 3-13.

Hartl, P., Tauxe, L. \& Constable, C., 1993. Early Oligocene geomagnetic field behaviour from deep sea drilling Project site 522. Journal of Geophysical Research 98: 19649-19665.

Hooyberghs, H., 1983. Contributions to the study of planktonic Foraminifera in the Belgian Tertiary. Aardkundige Mededelingen (Leuven University Press) 2: 131 pp.

Hooyberghs, H.J.F., 1992. Planktonic foraminiferal biostratigraphy in the Boom Formation at Kruibeke and Antwerp (Northern Belgium). In: Hooyberghs, H., Vercauteren, T., De Meuter, F. \& Symons, F. (eds): Foraminiferal studies in the Boom Formation. Professional Paper, Belgian Geological Survey (Brussels) 258: 1-10.

Laenen, B. \& De Craen, M., 2004. Eogenetic siderite as an indicator for fluctuations in sedimentation rate in the Oligocene Boom Clay Formation (Belgium). Sedimentary Geology 163: 165-174.
Lagrou, D., 1992. Magnetostratigrafie van de Boomse Klei in het stratotype gebied. Master thesis, KU Leuven, Leuven: 92 pp. (in Dutch).

Lowrie, W., 1990. Identification of ferromagnetic minerals in a rock by coercivity and unblocking temperature properties. Geophysical Research Letters 17: 159-162.

Lowrie, W. \& Lanci, L., 1994. Magnetostratigraphy of EoceneOligocene boundary sections in Italy: No evidence for short subchrons within chrons C12R and C13R. Earth and Planetary Science Letters 126: 247-258.

Martini, E., 1971. Standard Tertiary and Quaternary calcareous nannoplankton zonation. Proceedings of the second planktonic Conference in Roma 1970. Edizioni Tecnoscienza, Roma, 2: 739-785.

Mary, C., Iaccarino, S., Courtillot, V., Besse, J. \& Aissaoui, D.M., 1993. Magnetostratigraphy of Pliocene sediments from the Stirone river (Po Valley). Geophysical Journal International 112 : 359-380.

Mullender, T.A.T., Van Velzen, A.J. \& Dekkers, M.J., 1993. Continuous drift correction and separate identification of ferrimagnetic and paramagnetic contributions in thermomagnetic runs. Geophysical Journal International 114: 663-672.

Poore, R.Z., Tauxe, L., Percival Jr., S.F. \& LaBrecque, J.L., 1982. Late Eocene-Oligocene magnetostratigraphy and biostratigraphy at South Atlantic DSDP site 522. Geology 10: 508-511.

Prince, R.A., Heath, G.R. \& Kominz, M., 1980. Paleomagnetic studies of Central North Pacific sediment cores: Stratigraphy, sedimentation rates, and the origin of magnetic instability. Geological Society of America Bulletin 91: 1789-1835.

Reynolds, R.L., Tuttle, M.L., Rice, C.A., Fishman, N.S., Karachewski, J.A. \& Sherman, D.M., 1994. Magnetization and geochemistry of greigite-bearing Cretaceous strata, North Slope Basin, Alaska. American Journal of Science 294: 485-528.

Roberts, A.P., 1995. Magnetic properties of sedimentary greigite (Fe3S4). Earth and Planetary Science Letters 134: 227-236.

Roberts, A.P. \& Turner, G.M., 1993. Diagenetic formation of ferrimagnetic iron sulphide minerals in rapidly deposited marine sediments, South Island, New Zealand. Earth and Planetary Science Letters 115: 57-273.

Snowball, I.F., 1994. Bacterial magnetite and the magnetic properties of sediments in a Swedish lake. Earth Planetary Science Letters 126: 129-142.

Snowball, I.F. \& Thompson, R., 1990. A stable chemical remanence in Holocene sediments. Journal of Geophysical Research 95: 4471-4479.

Steurbaut, E., 1986. Late Middle Eocene to Middle Oligocene Calcareous nannoplankton from the Kallo well, some boreholes and exposures in Belgium and a description of the Ruisbroek Sand Member. Mededelingen Werkgroep Tertiair en Kwartair Geologie 23(2): 49-83.

Steurbaut, E., 1992. Integrated stratigraphic analysis of Lower Rupelian Deposits (Oligocene) in the Belgian basin. Annales de la Société Géologique de Belgique 115: 287-306.

Stover, L.E. \& Hardenbol, J., 1994. Dinoflagellates and depositional sequences in the Lower Oligocene (Rupelian) Boom Clay Formation, Belgium. Bulletin van de Belgische Vereniging voor Geologie 102(1-2): 5-77.

Thompson, R. \& Cameron, T.D.J., 1995. Paleomagnetic study of Cenozoic sediments in North Sea boreholes: an example of a magnetostratigraphic conundrum in a hydrocarbon producing area. In:Turner, P. \& Turner, A. (eds): Palaeomagnetic Applications in Hydrocarbon Exploration and Production. Geological Society London, Special Publication 98: 223-236. 
Vandenberghe, N., 1978. Sedimentology of the Boom Clay (Rupelian) in Belgium. Verhandelingen Koninklijke Academie Wetenschappen Letteren en Schone Kunsten van België, Klasse Wetenschappen (Brussel) 147:137 pp.

Vandenberghe, N. \& Laga, P., 1986. The septaria of the Boom Clay (Rupelian) in its type area in Belgium. Aardkundige Mededelingen (Leuven University Press) 3: 229-238.

Vandenberghe, N. \& Van Echelpoel, E., 1987. Field guide to the Rupelian stratotype. Bulletin van de Belgische Vereniging voor Geologie 96: 325-337.

Vandenberghe, N., Laenen, B., Van Echelpoel, E. \& Lagrou, D., 1997. Cyclostratigraphy and climatic eustasy. Example of the Rupelian stratotype. Comptes Rendus de l'Académie des Sciences (Paris), Sciences de la Terre et des Planètes 325: 305-315.

Vandenberghe, N., Laga, P., Steurbaut, E., Hardenbol, J. \& Vail, P., 1998. Tertiary Sequence Stratigraphy at the Southern Border of the North Sea Basin in Belgium. In: de Graciansky, P.C., Hardenbol, J., Jaquin, T. \& Vail, P.R. (eds): Mesozoic and Cenozoic Sequence Stratigraphy of European Basins. Society for Sedimentary Geology (SEPM), Special Publication 60: 119-154.

Van Hoof, A.A.M. \& Langereis, C.G., 1991. Reversal records in marine marls and delayed acquisition of remanent magnetization. Nature 351: 223-225.

Van Simaeys, S., De Man, E., Vandenberghe, N., Brinkhuis, H., Steurbaut, E., 2004. Stratigraphic and palaeoenvironmental analysis of the Rupelian-Chattian transition in the type region: evidence from dinoflagellate cysts, foraminifera and calcareous nannofossils. Palaeogeography, Palaeoclimatology, Palaeoecology 208: 31-58.
Van Velzen, A.J., Dekkers, M.J. \& Zijderveld, J.D.A., 1993. Magnetic iron-nickel sulphides in the Pliocene and Pleistocene marine marls from the Vrica section (Calabria, Italy). Earth and Planetary Science Letters 115: 43-55.

Wei, W. \& Wise, S.W., 1989. Discoaster praebifax n.sp. - A possible ancestor of Discoaster bifax Bukry (Coccolithophoridae). Journal of Paleontology 63: 10-14.

Williams, G.L., Brinkhuis, H., Pearce, M.A., Fensome, R.A., Weegink, J.W., 2004. Southern Ocean and global dinoflagellate cyst events compared; Index events for the Late CretaceousNeogene. In: Exon, N.F., Kennett, J.P. \& Malone, M.J. (eds), Proceedings of the Ocean Drilling Program, Scientific Results ODP Leg 189: 1-98 [Online]. Available from World Wide Web: <http://www-odp.tamu.edu/publications/189_SR/VOLUME/ CHAPTERS/107.PDF>.

Zijderveld, J.D.A., Hilgen, F.J., Langereis, C.G., Verhallen, P.J.J.M. \& Zachariasse, W.J., 1991. Integrated magnetostratigraphy and biostratigraphy of the upper Pliocene-lower Pleistocene from the Monte Singa and Crotone areas in Calabria, Italy. Earth and Planetary Science Letters 107: 697-714. 